\title{
Issues in Sustainability Accounting Reporting
}

\author{
Elena Munoz ${ }^{1}$, Lijuan Zhao ${ }^{2}$, Ph.D. \& David C. Yang ${ }^{1}$, Ph.D. \\ ${ }^{1}$ School of Accountancy, Shidler College of Business, University of Hawaii at Manoa, Honolulu, HI 96822, USA \\ 2 Department of Accounting, College of Business and Economics, California State University, Los Angeles, Los \\ Angeles, CA 90032, USA \\ Correspondence: Lijuan Zhao, Ph.D., Department of Accounting, College of Business and Economics, California \\ State University, Los Angeles, Los Angeles, CA 90032, USA
}

Received: July 10, 2017

Accepted: July 28, 2017

Online Published: August 1, 2017

doi:10.5430/afr.v6n3p64

URL: https://doi.org/10.5430/afr.v6n3p64

\begin{abstract}
In the U.S., sustainability accounting reporting is developing and becoming more prevalent in public companies. This paper reviews accounting literature and Dow 30 companies' websites, presents a comprehensive view of the landscape of sustainability accounting reporting, and identifies seven issues of the reporting frameworks of sustainability accounting, i.e., (1) definitions, (2) measurements and disclosures, (3) motivations, (4) compliance, (5) enforcement, (6) standardization, and (7) the ultimate effect on reliability and comparability.

An archival analysis approach is used to summarize and compare Dow 30 sustainability accounting reporting frameworks and information disclosed in 2015 annual reports and websites. The most popular framework is the Global Reporting Initiative (GRI) G4 Sustainability Reporting Guidelines. Some companies developed sustainability accounting reporting frameworks and others did not disclose any information regarding sustainability accounting reporting. Although the GRI framework is the most used, external assurance is present in only a few companies.
\end{abstract}

Keywords Sustainability Accounting Reporting, Sustainability Framework, Dow 30 Companies

\section{Introduction}

There is increased pressure on companies to take into account their social and environmental impacts which is largely due to sustainability accounting reporting guideline proliferation. The triple bottom line (TBL) approach examines social, environmental, and financial impacts of a company. The TBL is often reported as corporate social responsibility (CSR) activities and standardized in the United Nations (UN) Global Compact, the OECD Guidelines for Multinational Enterprises, and the Global Reporting Initiative (GRI).

In 1975, the first the CSR model appeared and was named corporate social performance (CSP) model appeared as a three-tier corporate behavior (Seth, 1975):

(1) Social obligation (representing the legal and market constraint),

(2) Social responsibility (societal norms and expectations), and

(3) Social responsiveness (anticipatory competence and preventative adaptation to social needs).

Then, in 1999, the model was expanded model was expanded to a four-tier model (Carroll, 1999):

(1) Economic (profitability),

(2) Legal (obedience to the rules of law),

(3) Ethical (avoid harm, do what is right and fair), and

(4) Discretional/ philanthropic (be a concerned corporate citizen for disadvantaged workers).

Through these frameworks, the CSR evolved from the 1950s and the primary focus was on businesses' responsibilities to society and doing good deeds for society to the 2000s and the role of CSR as an important strategic issue (Moura-Leite and Padgett, 2011). The purpose of this study is to examine the current practice of sustainability accounting reporting and identify issues of sustainability accounting reporting. A survey of 2015 annual reports and websites of Dow 30 companies was performed. 


\section{Literature Review and Method}

Table 1. Survey of 2015 Sustainability Accounting Reporting of Dow 30 Companies

\begin{tabular}{|c|c|c|c|}
\hline Company & Sustainability Framework & $\begin{array}{l}\text { External } \\
\text { Assurance }\end{array}$ & Standard Applied \\
\hline MMM 3M & $\begin{array}{l}\text { GRI, ISO } 14001 \text {-certified (or } \\
\text { equivalent), United Nations } \\
\text { Global Compact Communication } \\
\text { on Progress }\end{array}$ & $\begin{array}{lr}\text { Bureau } & \text { Veritas } \\
\text { North } & \text { America, } \\
\text { Inc. } & \text { (Bureau } \\
\text { Veritas) } & \end{array}$ & $\begin{array}{l}\text { Assurance Standard AA10000AS } \\
\text { (2008) Type } 2 \text { assurance. }\end{array}$ \\
\hline $\begin{array}{l}\text { AXP American } \\
\text { Express }\end{array}$ & $\begin{array}{l}\text { No Current Report, Self- } \\
\text { Developed: Carbon Disclosure } \\
\text { Project }\end{array}$ & None & \\
\hline \multirow[t]{2}{*}{ AAPL Apple } & $\begin{array}{l}\text { ISO } 14040 / 14044 \text { Environmental } \\
\text { Management, ISO 14064-3 } \\
\text { Greenhouse Gases }\end{array}$ & $\begin{array}{lr}\text { Bureau } & \text { Veritas } \\
\text { North } & \text { America, } \\
\text { Inc. } & \text { (Bureau } \\
\text { Veritas) } & \end{array}$ & $\begin{array}{l}\text { World Resources Institute } \\
\text { (WRI)/World Business Council for } \\
\text { Sustainable } \\
\text { (WBCSD) Gevelopment } \\
\text { Protocol International Standard on } \\
\text { Assurance Engagements (ISAE) } \\
3000\end{array}$ \\
\hline & & $\begin{array}{l}\text { Fraunhofer } \\
\text { Institute }\end{array}$ & ISO 14046-3 \\
\hline BA Boeing & $\begin{array}{lr}\text { Self-Developed: } & \text { CDP, } \\
\text { International } & \text { Aerospace } \\
\text { Environmental Group Greenhouse } & \text { Gas (GHG) Reporting Guidance }\end{array}$ & None & \\
\hline CAT Caterpillar & GRI & None & \\
\hline CVX Chevron & $\begin{array}{l}\text { Self-Developed: Operational } \\
\text { Excellence Management System } \\
\text { (OEMS) based on } \\
\text { IPIECA/API/IOGP Oil and gas } \\
\text { industry guidance on voluntary } \\
\text { sustainability reporting (2015) }\end{array}$ & $\begin{array}{l}\text { Lloyd's Register } \\
\text { Quality Assurance } \\
\text { Ltd. (LRQA) }\end{array}$ & $\begin{array}{l}\text { ISO 14001:2004 and OHSAS } \\
\text { 18001:2007 }\end{array}$ \\
\hline CSCO Cisco & $\begin{array}{l}\text { GRI, United Nations Global } \\
\text { Compact LEAD Program } \\
\text { Advanced Criteria, United } \\
\text { Nations Global Compact } \\
\text { Communication on Progress }\end{array}$ & None & ISO 14001 \\
\hline KO Coca-Cola & GRI & $\mathrm{EY}$ & review level \\
\hline DIS Disney & GRI & Ceres & review level \\
\hline $\begin{array}{l}\text { DD E I du Pont de } \\
\text { Nemours and Co }\end{array}$ & GRI, CDP & WSP & ISO 14064-3, ISO 14065 \\
\hline XOM Exxon Mobil & IPIECA, OGP, API and GRI & $\begin{array}{l}\text { Lloyd's Register } \\
\text { Quality Assurance, } \\
\text { Inc }\end{array}$ & ISO 9001 and ISO 14001 \\
\hline GE General Electric & GRI & Internal audit & \\
\hline GS Goldman Sachs & $\begin{array}{l}\text { Self-Developed: Environmental } \\
\text { Policy Framework, CDP }\end{array}$ & & \\
\hline HD Home Depot & GRI & None & \\
\hline
\end{tabular}




\begin{tabular}{|c|c|c|c|}
\hline IBM IBM & GRI, OneReport & $\begin{array}{l}\text { Bureau Veritas } \\
\text { Certification }\end{array}$ & ISO 14001, ISO 50001 \\
\hline INTC Intel & GRI, CDP & EY & review level, ISO 14001 \\
\hline $\begin{array}{l}\text { JNJ Johnson } \quad \& \\
\text { Johnson }\end{array}$ & GRI & $\begin{array}{l}\text { ERM Certification } \\
\text { and Verification } \\
\text { Services } \\
\text { CVS) }\end{array}$ & ISAE 3000 \\
\hline $\begin{array}{l}\text { JPM JPMorgan } \\
\text { Chase }\end{array}$ & GRI & None & \\
\hline MCD McDonald's & GRI & None & \\
\hline MRK Merck & GRI, UNGC, CDP & WSP & ISO 14064-3 \\
\hline MSFT Microsoft & GRI & None & ISO 14001 \\
\hline NKE Nike & GRI, UNGC & None & \\
\hline PFE Pfizer & GRI & None & \\
\hline $\begin{array}{l}\text { PG Procter } \quad \& \\
\text { Gamble }\end{array}$ & GRI & $\begin{array}{l}\text { None, } \\
\text { Environmental } \\
\text { Resources } \\
\text { Management } \\
\text { (ERM) in } 2010\end{array}$ & OSHAS 18001 and ISO 14001. \\
\hline
\end{tabular}

\begin{tabular}{|c|c|c|c|}
\hline $\begin{array}{l}\text { TRV Travelers } \\
\text { Companies Inc. }\end{array}$ & $\begin{array}{l}\text { None } \\
\text { Provided CDP Response }\end{array}$ & None & \\
\hline $\begin{array}{l}\text { UTX United } \\
\text { Technologies }\end{array}$ & $\begin{array}{l}\text { Self-Developed: Greenhouse } \\
\text { Gases }\end{array}$ & None & \\
\hline UNH UnitedHealth & $\begin{array}{l}\text { Informal } \\
\text { Self-Developed: } \\
\text { Performance Indicators }\end{array}$ & None & \\
\hline VZ Verizon & GRI & EY & $\begin{array}{l}\text { Review level (verified The } \\
\text { Greenhouse Gas Protocol: A } \\
\text { Corporate Accounting and } \\
\text { Reporting Standard Revised } \\
\text { Edition by the World } \\
\text { Resources Institute (WRI)/World } \\
\text { Business Council for Sustainable } \\
\text { Development (WBCSD). } \\
\text { US Environmental Protection } \\
\text { Agency (EPA) 2008 Climate } \\
\text { Leaders Greenhouse } \\
\text { Gas Reporting Protocol: Direct } \\
\text { Emissions from Stationary and } \\
\text { Mobile Combustion Sources } \\
\text { Intergovernmental Panel on } \\
\text { Climate Change (IPCC) Fourth } \\
\text { Assessment Report (2007)) }\end{array}$ \\
\hline V Visa & GRI & $\begin{array}{l}\text { None, Internal } \\
\text { assessment }\end{array}$ & ISO 14001 \\
\hline WMT Wal-Mart & GRI & None & \\
\hline
\end{tabular}

Table 1 clearly shows that GRI is the most widely used standard for sustainability accounting reporting. The GRI was initiated by CERES (http://www.ceres.org) and the UN Environment Program in 1997. In 2002, the GRI became an 
independent body to create a language which could be used by others to form judgments about the reported performance, and which could over time lead to the emergence of a societal consensus about what constitutes acceptable norms of behavior with regard to sustainability. Additionally, the International Standards Organization (ISO), the World Business Council for Sustainable Development (WBCSD), AccountAbility, the Sustainability Integrated Guidelines for Management project (SIGMA), the Carbon Disclosure Project (CDP), the United Nations Global Compact (UNGC), and Business in Community (BITC) have issued sustainability accounting reporting related standards.

There are several issues concerning sustainability accounting reporting concerning both in concept and in practice. According to (Slager, Gond \& Moon, 2012) there are three components to that comprise the regulatory power of a standard. The first is design which is the established set of common practices. The second is legitimacy which is the authority based on multiple stakeholders. The third and last is monitoring which is rule enforcement through the monitoring of practices. Although there is a mutually agreed upon concept of sustainability accounting reporting in that more than just financial information should be provided, there is a lack of uniformity in just the first component of design. Without the first component of an established set of common practices, there is no progression to legitimacy or monitoring.

In the accounting literature, some posit that the TBL is not an approach to sustainability accounting reporting (Gray and Milne, 2004). The TBL approach is criticized as a misrepresentation of the sustainability issues, as a means of buying off conflict, and as an active failure to recognize that the financial will always dominate any kind of bottom line in capitalism (Gray and Milne, 2004). There are debates about (a) definitions, (b) measurements and disclosures, (c) motivations, (d) compliance, (e) enforcement, (f) standardization, and (g) the ultimate effect on reliability and comparability.

\section{a. Definitions}

Although there is a growing body of sustainability reporting guidelines, there is a concern that the further standardization is needed. Primarily, there is no consensus as to what to term the concept that demonstrate the fundamental lack of uniformity. Despite their different names, triple bottom line reporting, social and environmental reports, sustainability reports, and corporate social responsibility reports, each reporting mechanism attempts to account for their social and environmental impacts (Archel, Fernandez \& Larrinaga, 2008). Elkington's Measurement Claim (Elkington, 1997) explains that social performance and impact can be measured in relatively objective ways. The Aggregation Claim (Elkington, 1997) is a social profit or loss that can be calculated using data from standard indicators and a relatively uncontroversial formula that could be used for any firm. The Aggregation Claim is not achieved because there is not method or formula in the framework to aggregate across the principles. As a result, there is confusion as to the approach to profit maximization.

\section{b. Measurements and Disclosures}

With the inconsistent definitions, there are inconsistent measurements. The social responsibility of sustainability is the most challenging to measure and quantify (Christofi, Christofi \& Sisaye, 2012). There is a duality between the stated aims of the GRI and its actual use in corporations (Vigneau, Humphreys \& Moon, 2014).

In sustainability accounting reporting, selective disclosure presents a potential bias. Regulators should consider mandating some of these disclosures and standardizing certain aspects of disclosures to prevent companies from concealing negative or bad news and disclosing positive or good news. If leading indicator disclosures are mandated or assured by external professional accountants, the reliability of these disclosures could potentially increase in the future (Coram, Monroe \& Woodliff, 2009).

\section{c. Motivations}

Additionally, the motivation and desire for compliance is unclear. Isomorphism coerces one actor within a population to mimic the other actors and is categorized as three types, coercive, mimetic, and normative. Companies are influenced by coercive, normative and mimetic isomorphism when adopting sustainability reporting frameworks. External factors like stakeholders, government, and regulations are coercive. Peer influence is mimetic and normative. There is a disproportionate implementation of sustainability practices with an emphasis on domestic sustainability which is lacking in the international operations of a company (Hashmi, Damanhouri \& Rana, 2015). Companies in the U.S. are closely scrutinized by environmental groups that are also based in the U.S. and this motivates the companies to emphasize sustainability domestically rather than internationally. 
Sustainability indices, such as the Dow Jones Sustainability Index (DJSI), create external pressures for companies and lead to fixation on selection criteria, rather than improvements in areas that are more relevant to the company. This undermines the objective of sustainability accounting reporting.

\section{d. Compliance}

Another criticism is the methods of certification and compliance. Although the ISO 14001 provides requirements with guidance for use, the international standard on environmental management systems does not provide specific performance requirements (Sidhar, 2013). The other issue regarding compliance is that sustainability accounting reporting is voluntary and therefore do not require attestation by a third party. Unlike financial reporting, the company must engage an external auditor to attest to not only the reliability of financial statements, but also to management's assertion of the internal controls over financial reporting. The external assurance not only encourages compliance, but also discourages fraudulent acts because of the possibility that the act will be noticed. Given that this practice is voluntary, only some companies practice sustainability accounting reporting and fewer provide external assurance.

The guidelines of sustainability accounting reporting have replaced the evaluation of CSR and the development of company specific standards. The GRI standardized some forms of CSR management practices by institutionalizing CSR information and the associated reporting and norms (Brown, de Jong \& Levy, 2001). In actuality, organizational actors and companies employ the reporting principles as management guidelines by viewing the GRI as a CSR performance assessment tool (Vigneau, Humphreys \& Moon, 2014).

\section{e. Enforcement}

Given that sustainability accounting reporting is voluntary, there is no authority that will penalize a company for noncompliance. Additionally, the companies that practice sustainability accounting reporting do not face penalization if there are misstatements, but again it is less likely that there will be misstatements because the company can develop its own framework.

Additionally, there is no standardized approach to corrective action. The company judges the negative effect or impact as being so important to take corrective action. In these cases, the company implicitly takes responsibility for the occurrence of the negative aspect. Other companies provide a more formalized and concrete approach (Hahn and Lulfs, 2014).

\section{f. Standardization}

There is a multitude of sustainability reporting guidelines with numerous approaches. This leads to a lack of uniformity and comparability across companies. Additionally, the standards and indices should focus not only on the overall sustainability performance, but also stratify performance by industry. The one size fits all approach to sustainability reporting is not conducive to a diverse economy (Sidhar, 2013). In terms of disclosure, there are discernible trends for each industry. Disclosures have strategic focus and competitive landscapes within which different industries operate as well as presence of industry-specific success factors such as the heavy dependence on human resources or individual-specific intellectual capital (Cohen, Holder-Webb, Nath \& Wood, 2012). Although the GRI released some guidelines for specific industries like utilities and financial institutions among others (GRI, 2013), there is still a need to include more industries and improve the breadth and depth, as well as the uniformity, of the existing sustainability reporting standards.

\section{g. Effect on reliability and comparability}

An enormous diversity is evident with regards to categories, decision rules, definitions and even measurement approaches, undermining the comparability of findings and the accumulation of knowledge (Vourvachis and Woodward, 2015). 


\section{Empirical Results}

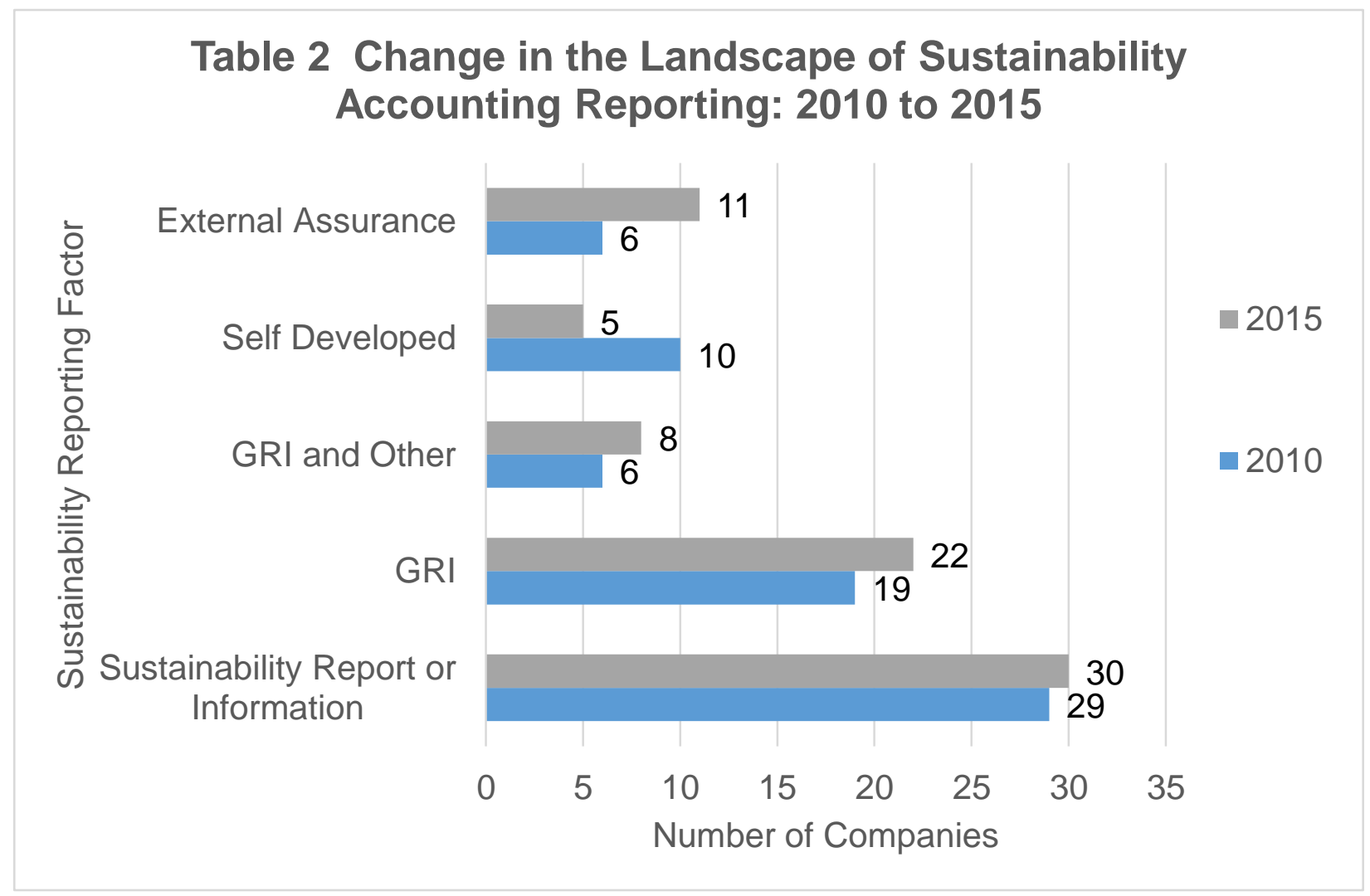

Table 2 shows that there are 22 companies that incorporate the GRI standards in their sustainability accounting reports. There are 14 companies that exclusively use the GRI standards. However, there are only 11 companies that provide sustainability accounting reports and external assurance. The accounting firm Earst \& Young (EY) performed the most engagements with 3 out of 11 companies. Other external assurance is provided by Bureau Veritas North America, Inc. (Bureau Veritas), Fraunhofer Institute, Lloyd's Register Quality Assurance, Inc., Environmental Resources Management, and WSP. The general trend is an increase in the companies that use the GRI standards and the companies that provide external assurance. However, compared to 2010, there are two more companies using the UN Global Compact and industrial specified reporting standards (Guo and Yang, 2014). It is interesting to note that there are more companies using multiple standards. This may be associated with the inability to apply a one size fits all approach and the need for industry specific guidelines.

There are 5 companies that developed a sustainability accounting reporting framework. The most common feature of the self-developed sustainability frameworks is greenhouse gas emissions and adopts guidelines and terminology from the CDP. Compared to 2010 (Guo and Yang, 2014), there is a decrease in self-developed frameworks and an increase in the adoption of GRI standards.

There is one company that does not provide a formal sustainability accounting report, The Travelers Companies, Inc. Additionally, UnitedHealth Group Incorporated did not provide a formal sustainability accounting report, meaning that its informal report comprised only infographics, a reference to sustainability in the annual report, or references to policies and an absence of a qualitative report incorporating the all of the material. The two companies that did not provide formal sustainability accounting reports were both from insurance industries and added in 2009 or later. This is in accordance with previous literature that demonstrated lack of sustainability accounting reporting in the insurance industry (Guo and Yang, 2014). The Travelers Companies, Inc. did not provide a formal sustainability report, but provided the response to the CDP and Insurer Climate Risk Survey. Interestingly, although The Travelers Companies, Inc. and UnitedHealth Group Incorporated do not provide a formal sustainability report, both are included in the DJSI. The Travelers Companies, Inc. states in the 2014 Annual Report that all Travelers-owned campuses are ENERGY STAR ${ }^{\circ}$ Certified. 
All companies provided information on sustainability accounting reporting which is an increase from $96.7 \%$ in 2010 (Guo and Yang, 2014). The increasing trend in sustainability accounting reporting demonstrates the perceived value of sustainability accounting reporting. Although the practice is voluntary, all of the Dow 30 companies participate in sustainability accounting reporting in some way.

\section{Conclusions}

Although there is improvement and progress in terms of sustainability accounting reporting, there is a lack of research and support as to the effectiveness of sustainability accounting reporting. Substantive sustainability accounting reporting is the first significant and sensible step to begin to expose the extent to which the potential doomsday scenarios are worthy of our attention or not (Gray, 2006). Gray continues to explain that this action and sustainability reporting can potentially lead to the actual "release shareholder value" in the sense that it might lead to activities that ensured shareholders might still be alive. This is an important point and requires a change in the established mindset to one of a longer horizon.

\section{Discussions}

One of the limitations of this study is that the research is limited to participants in the Dow 30 . This includes only public companies in the U.S. Further research can be conducted in various geographic regions and even on a global scale. Another direction for research includes a survey of the DJSI and RobecoSAM leaders. This again can be stratified by industry, region, and a comprehensive global outlook. By studying the sustainability industry leaders, there will be better insight as to best practices for sustainability accounting reporting in that industry. Additionally, the research will support the need for more industry specific guidelines in sustainability accounting reporting and provide direction for that change.

\section{References}

Archel, P., Fernández, M. \& Larrinaga, C. (2008). The Organizational and Operational Boundaries of Triple Bottom Line Reporting: A Survey. Environmental management, 41(1), 106-17. https://doi.org/10.1007/s00267-007-9029-7

Brown, H. S., de Jong, M., \& Levy, D. L. (2009). Building institutions based on information disclosure: Lessons from GRI's sustainability reporting. Journal of Cleaner Production, 17(6), 571-580. https://doi.org/10.1016/j.jclepro.2008.12.009

Carroll, A. (1999). Corporate social responsibility. Business and Society, 38(3), 268-95. https://doi.org/10.1177/000765039903800303

Christofi, A., Christofi, P. \& Sisaye, S. (2012). Corporate sustainability: historical development and reporting practices. Management Research Review, 35(2), 157-172. https://doi.org/10.1108/01409171211195170

Cohen, J.R., Holder-Webb, L., Nath, L. \& Wood, D. (2012). Corporate Reporting of Nonfinancial Leading Indicators of Economic Performance and Sustainability. Accounting Horizons, 26(1), 65-90. https://doi.org/10.2308/acch-50073

Coram, P.J., Monroe, G.S. \& Woodliff, D.R. (2009). The Value of Assurance on Voluntary Nonfinancial Disclosure: An Experimental Evaluation. Auditing, 28(1), 137-151. https://doi.org/10.2308/aud.2009.28.1.137

Elkington, J. (1997). Cannibals with forks: the triple bottom line of 21st century business. USA: New Society Publishers.

Global Reporting Initiative. (2013). G4 Sustainability Reporting Guidelines, Version 4. Amsterdam, Netherlands: GRI.

Gray, R. (2006). Social, environmental and sustainability reporting and organisational value creation? Accounting, Auditing \& Accountability Journal, 19(6), 793-819. https://doi.org/10.1108/09513570610709872

Gray, R.H. \& Milne, M. (2004). Towards reporting on the triple bottom line: mirages, methods and myths, in Henriques, A. and Richardson, J. (Eds), The Triple Bottom Line: Does it all Add Up?, Earthscan, London, pp. 70-80.

Guo, Y. \& Yang, D.C. (2014). Sustainability Accounting Reporting: A Survey on 30 U.S. Dow-Jones Companies. International Journal of Accounting and Taxation, 2(3), 1-15. https://doi.org/10.15640/ijat.v2n3a1 
Hahn, R. \& Lülfs, R. (2014). Legitimizing Negative Aspects in GRI-Oriented Sustainability Reporting: A Qualitative Analysis of Corporate Disclosure Strategies. Journal of Business Ethics, 123(3), 401-420. https://doi.org/10.1007/s10551-013-1801-4

Hashmi, M.A., Damanhouri, A. \& Rana, D. (2015). Evaluation of Sustainability Practices in the United States and Large Corporations. Journal of Business Ethics, 127(3), 673-681. https://doi.org/10.1007/s10551-014-2056-4

Jeurissen, R. (2000). Cannibals with Forks: The Triple Bottom Line of 21st Century Business. Journal of Business Ethics, 23(2), 229-231. https://doi.org/10.1023/A:1006129603978

Moura-Leite, R. \& Padgett, R.C. (2011). Historical background of corporate social responsibility. Social Responsibility Journal, 7(4), 528-539. https://doi.org/10.1108/1747111111117511

Sethi, S.P. (1975). Dimensions of corporate social performance: an analytic framework. California Management Review, 17. https://doi.org/10.2307/41162149

Slager, R., Gond, J.-P., \& Moon, J. (2012). Standardization as institutional work: The regulatory power of a responsible investment standard. Organization $\quad$ Studies, $\quad 33(6), \quad 763-790$. https://doi.org/10.1177/0170840612443628

Sridhar, K. \& Jones, G. (2013). The three fundamental criticisms of the Triple Bottom Line approach: An empirical study to link sustainability reports in companies based in the Asia-Pacific region and TBL shortcomings. Asian Journal of Business Ethics, 2(1), 91-111. https://doi.org/10.1007/s13520-012-0019-3

Vigneau, L., Humphreys, M. \& Moon, J. (2015). How Do Firms Comply with International Sustainability Standards? Processes and Consequences of Adopting the Global Reporting Initiative. Journal of Business Ethics, 131(2), 469-486. https://doi.org/10.1007/s10551-014-2278-5

Vourvachis, P. \& Woodward, T. (2015). Content analysis in social and environmental reporting research: trends and challenges. Journal of Applied Accounting Research, 16(2), 195. https://doi.org/10.1108/JAAR-04-2013-0027 